\title{
ФУНКЦІОНАЛЬНИЙ СТАН ПРООКСИДАНТНОЇ ТА АНТИОКСИДАНТНОЇ СИСТЕМ У ЛЕГЕНЯХ ПРИ ЕКСПЕРИМЕНТАЛЬНОМУ АЛЕРГІЧНОМУ АЛЬВЕОЛІТІ В УМОВАХ ІММОБІЛІЗАЦІЙНОГО СТРЕСУ ТА КОРЕКЦІЯ ЙОГО ПОРУШЕНЬ КОРВІТИНОМ
}

Вступ. Серед захворювань алергічного генезу бронхолегеневого апарату важливе місце посідає експериментальний алергічний альвеоліт (EAA). Різке погіршення сочіально-економічного стану в Україні, висока психоемоційна напруга в суспільстві, тривалий систематичний вплив несприятливих фракторів часто поєднуються, викликаючи в організмі стресову реакцію.

Мета дослідження - вивчити фрункціональний стан прооксидантної та антиоксидантної систем у легенях мурчаків-самок за умов розвитку експериментальних іммобілізаційного стресу й алергічного альвеоліту і при їх корекції корвітином.

Методи дослідження. Об'єктом дослідження були 80 мурчаків-самок, поділених на 8 експериментальних груп по 10 тварин у кожній: 1-ша - інтактні тварини; 2-4 - експериментальна модель алергічного альвеоліту (1-ша, 2-га, 34-та доби) до лікування корвітином (Борщагівський хіміко-фрармацевтичний завод); 5-7 - ЕАА за умов експериментального іммобілізаційного стресу (EIC) (1-ша, 2-га, 34-та доби) до лікування корвітином; 8-ма - EAA при ЕІС (34-та доба) після лікування корвітином, який вводили внутрішньочеревно протягом 10-ти діб у дозі 40 мг/кг. Потім тварин декапітували і визначали в легенях вміст продуктів пероксидного окиснення ліпідів та активність фрерментів антиоксидантної системи: вміст дієнових кон'югатів - за методом В. Б. Гаврилова, М. І. Мішкорудної, малонового діальдегіду - за методом Е. Н. Коробейникової, активність супероксиддисмутази - за методом R. Fried, каталази - за методом R. Holmes, C. Masters. Експериментальний іммобілізаційний стрес відтворювали за методом П. Д. Горизонтова, експериментальний алергічний альвеоліт - за методом О. О. Орєхова, Ю. А. Кирилова. Статистичну обробку цифрових даних проводили за t-критерієм Стьюдента. Статистично достовірними вважали результати, при яких рх0,05.

Результати й обговорення. Під час експериментальних досліджень спостерігали зміну активності антиоксидантного захисту та пероксидного окиснення ліпідів у динаміці розвитку ЕАA, а також зміну рівноваги між прооксидантною та антиоксидантною системами в бік стимуляції прооксидантної і пригнічення антиоксидантної. Відзначали значну активацію антиоксидантних механізмів на 1-шу добу з поступовим виснаженням на 34-ту добу захворювання та посиленням процесів ліпопероксидації на 34-ту добу. За умов поєднання патологічних процесів (експериментальних алергічного альвеоліту та іммобілізаційного стресу) спостерігали значну стимуляцію прооксидантної і пригнічення антиоксидантної систем. Після лікування впродовж 10-ти днів мурчаків з ЕАA за умов ЕIC, яким вводили корвітин у дозі 40 мг/ке, значно пригнічувалось пероксидне окиснення ліпідів і зростала активність антиоксидантної системи супероксиддисмутази.

Висновки. Отримані результати дослідження показали неспроможність антиоксидантної системи утилізувати продукти пероксидного окиснення ліпідів при EAA за умов EIC та їі виснаження ще в ранні періоди захворювання. При використанні корвітину, який має мембраностабілізувальну, імунокорегувальну, протизапальну й антиішемічну дію, зменшилась ушкоджувальна дія пероксидного окиснення ліпідів і значно підвищився антиоксидантний захист, що, у свою чергу, свідчить про корегувальний вплив корвітину на показники прооксидантної та антиоксидантної систем і дає можливість проводити подальше вивчення та експериментальні дослідження.

КЛЮчОВІ СЛОВА: експериментальний алергічний альвеоліт; іммобілізаційний стрес; корвітин.

ВСТУП. На сьогодні найпоширенішою патологією в структурі захворюваності населення України залишаються хвороби органів дихання. Серед причин, які сприяють зростанню захворюваності населення України на патологію дихальної системи, вітчизняні автори відзначають дію екзогенних фракторів, що дестабілізують го(c) М. С. Регеда, М. Є. Ковальська, 2018. меостаз людини (загазованість, запиленість повітря), різке погіршення соціально-економічного стану в Україні, високу психоемоційну напругу в суспільстві, тривалий систематичний вплив малих доз радіації [1].

Алергічні захворювання сьогодні охоплюють близько 20-30 \% населення земної кулі, й щороку спостерігають тенденцію до зростання їх 
кількості. Серед захворювань алергічного генезу бронхолегеневого апарату важливе місце посідає експериментальний алергічний альвеоліт (EAA) [2, 3].

Нині вже відомі причини виникнення цього захворювання, проте патогенетичних механізмів його формування до кінця не з'ясовано. Відомо, що суттєву роль для патогенезу ЕАА відіграють процеси пероксидного окиснення ліпідів (ПОЛ) і антиоксидантна система. Однак нез'ясованим залишається питання, що стосується змін прооксидантної та антиоксидантної систем в імунокомпетентних органах при EAА. Дія різних несприятливих чинників часто поєднується, викликаючи в організмі стресову реакцію. При цьому в легенях під впливом стресорів можуть відбуватись виражені структурні зміни, які є фактором виникнення та розвитку різноманітної бронхолегеневої патології $[4,5]$.

Мета дослідження-вивчити функціональний стан прооксидантної та антиоксидантної систем у легенях мурчаків-самок за умов розвитку поєднаної патології, а саме експериментальних іммобілізаційного стресу (EIC) й алергічного альвеоліту, і при їх корекції корвітином.

МЕТОДИ ДОСЛІДЖЕННЯ. Об'єкТОМ дослідження були 80 мурчаків-самок, поділених на 8 експериментальних груп по 10 тварин у кожній: 1-ша - інтактні тварини (контроль); 2-4 - експериментальна модель алергічного альвеоліту (1-ша, 2-га, 34-та доби) до лікування корвітином (Борщагівський хіміко-фрармацевтичний завод); 5-7 - експериментальна модель алергічного альвеоліту за умов EIC (1-ша, 2-га, 34-та доби) до лікування корвітином; 8-ма - експериментальна модель алергічного альвеоліту при ЕIC (34-та доба) після лікування корвітином, який вводили внутрішньочеревно протягом 10-ти діб у дозі 40 мг/кг.

Потім тварин декапітували і визначали в легенях вміст продуктів ПОЛ та активність ферментів антиоксидантної системи: вміст дієнових кон'югатів (ДК) - за методом В. Б. Гаврилова, М. І. Мішкорудної [6], малонового діальдегіду (МДА) - за методом Е. Н. Коробейникової [7], активність супероксиддисмутази (СОД) - за методом R. Fried [8], каталази (КT) - за методом R. Holmes, C. Masters [9]. Експериментальний іммобілізаційний стрес відтворювали за методом П. Д. Горизонтова [10], експериментальний алергічний альвеоліт - за методом О. О. Орєхова, Ю. А. Кирилова [11]. Статистичну обробку цисррових даних проводили з використанням загальноприйнятого методу Стьюдента. Статистично достовірними вважали результати, при яких $\mathrm{p} \leq 0,05$.
РЕЗУЛЬТАТИ Й ОБГОВОРЕННЯ. ПіД ЧАС експериментальних досліджень спостерігали зміну активності антиоксидантного захисту та пероксидного окиснення ліпідів у динаміці розвитку EAA. Уже на 1-шу добу розвитку EAA відбувалося незначне зростання вмісту в легенях СОД і КТ - на 1,8 та 3,29 \% відповідно, а також активності ДК і МДА - на 35,37 та 21,54 \% порівняно з контролем, що свідчило про активацію процесів пероксидації та антиоксидантної системи в мурчаків. На 2-гу добу при EAA і надалі зберігалося накопичення продуктів ПОЛ: збільшення ДК на 43,39 \%, МДА - на 26,39 \% і паралельне зростання показників СОД на 14,54 \%, КТ - на 15,14 \% відповідно до величин інтактних тварин, що вказувало на продовження стимуляції прооксидантних та антиоксидантних систем. Пізніше, на 34-ту добу розвитку EAA, спостерігали активацію антиоксидантного захисту: підвищення СОД на 29,44 \%, КТ - на $44,91 \%$ та значне нагромадження продуктів ПОЛ у легенях: зростання вмісту ДК на 200,58 \%, МДА - на 94,13 \% порівняно з групою здорових тварин.

Отже, на даному етапі виявлено помітні зміни рівноваги між прооксидантною та антиоксидантною системами в бік стимуляції прооксидантної і пригнічення антиоксидантної. Відзначали значну активацію антиоксидантних механізмів до 1-ї доби з поступовим виснаженням до 34-ї доби захворювання та посиленням процесів ліпопероксидації до 34-ї доби.

За умов поєднання патологічних процесів (експериментальних алергічного альвеоліту та іммобілізаційного стресу) на 1-шу добу спостерігали значне зростання показників як ПОЛ, так і антиоксидантної системи: збільшення СОД на $29,52 \%$, КТ - на 17,32 \%; МДА - на 118,22 \%, ДК - на 250,74 \% порівняно з контролем. Проте на 2-гу добу відзначали виснаження антиоксидантної системи: зменшення СОД на 31,83 \%, КТ - на 54,93 \% з поступовим зростанням ДК на 151,74 \%, МДА - на 89,57 \% проти величин інтактних тварин, що свідчило про значну стимуляцію прооксидантної і пригнічення антиоксидантної систем. На 34-ту добу EAA за умов ЕIC встановлено і надалі пригнічення антиоксидантного захисту: зниження СОД на $39,80 \%$, КТ - на 54,93 \% та продовження накопичення продуктів пОЛ: збільшення ДК на 140,3 \%, МДА - на 82,5 \% порівняно з групою здорових тварин.

Після лікування впродовж 10-ти днів мурчаків 3 EAA за умов ЕІС, яким вводили корвітин у дозі 40 мг/кг, спостерігали значне пригнічення ПОЛ: зменшення ДК на 69,26 \%, МДА - на $36,35 \%$ та зростання активності антиоксидантної системи: збільшення СОД на 39,8 \%, КТ - на 
56,8 \% порівняно з групою тварин, яких не піддавали дії цього препарату.

ВИСНОВКИ. Отримані результати дослідження показали неспроможність антиоксидантної системи утилізувати продукти ПОЛ при ЕАА за умов EIC та її виснаження ще в ранні періоди захворювання. При використанні корвітину, який має мембраностабілізувальну, імунокорегувальну, протизапальну та антиішемічну дію, зменшилась ушкоджувальна дія ПОЛ і значно підвищився антиоксидантний захист, що, у свою чергу, свідчить про корегувальний вплив корвітину на показники прооксидантної та антиоксидантної систем і дає можливість проводити подальше вивчення та експериментальні дослідження.

\section{СПИСОК ЛІТЕРАТУРИ}

1. Регеда М. С. Алергічні захворювання легенів : монографрія / М. С. Регеда. - Львів, 2009. - 342 с.

2. Регеда М. С. Екзогенний алергічний альвеоліт / М. С. Регеда, Ф. Й. Щепанський // Лікування та діагностика. - 2005. - № 2. - С. 45-71.

3. Преморбідні зміни легеневої тканини внаслідок гострої стресової реакції в експерименті / О. М. Проніна, М. М. Коптев, С. І. Данильченко [та ін.] // Вісн. проблем біології і медицини. - 2011. - 2 (88), вип. 3. С. 154-156.

4. Респираторная медицина : руководство в 2 т. / [В. Н. Абросимов, С. Н. Авдеев, О. Е. Авдеева и др.] ; под ред. А. Г. Чучалина. - М. : ГЭОТАР-Медиа, 2007. T. 1. -797 c.

5. Ватутін М. Т. Флавоноїд кверцетин: фармакологічні властивості та клінічне використання / М. Т. Ватутін, Т. С. Гончаренко, О.В.Склянна // Ліки. - 2005. № 3-4. - С.19-26.

6. Гаврилов В. Б. Спектрофотометрическое определение содержания гидроперекисей липидов в плазме / В. Б. Гаврилов, М. И. Мишкорудная // Лабораторная диагностика ишемической болезни сердца. - К. : Здоров'я, 1989. - С. 170-171.

7. Коробейникова Э. Н. Модификация определения продуктов перекисного окисления липидов в реакции с тиобарбитуровой кислотой / Э. Н. Коробейникова // Лаб. дело. - 1989. - № 7. - С. 8-10.

8. Fried, R. (1975). Enzymatic and non-enzymatic assay of super oxide dismutase. Biochemie, (57), 65, 657-660.

9. Holmes, R. \& Masters, C. (1970). Epigenetic interconversions of the multiple forms of mouse liver catalase. FEBS Lett., (11), 1, 45-48.

10. Горизонтов П. Д. Стресс и система крови / П. Д. Горизонтов, О. И. Белоусова, М. И. Федотова. М. : Медицина, 1983. - 239 с.

11. Орехов О. О. Патоморорология легких и микроциркуляторного русла малого круга кровообращения при хроническом экспериментальном аллергическом альвеолите / О. О. Орехов, Ю.А.Кирилов // Арх. патологии. - 1985. - № 10. - С. 54-61.

\section{REFERENCES}

1. Reheda M. S. (2009). Alerhichni zakhvoriuvannia leheniv: monohrafiia [Allergic diseases of the lungs: monograph]. Lviv [in Ukrainian].

2. Reheda, M.S., \& Shchepanskyi, F.Y. (2005). Ekzohennyi alerhichnyi alveolit [Exogenous allergic alveolitis]. Likuvannia ta diahnostyka - Treatment and Diagnostics, 2, 45-71 [in Ukrainian].

3. Pronina, O.M., Koptev, M.M., \& Danylchenko, S.I. (2011). Premorbidni zminy lehenevoi tkanyny vnaslidok hostroi stresovoi reaktsii v eksperymenti [Premorbid changes in the pulmonary tissue as a result of acute stress reaction in the experiment]. Visnyk problem biol. $i$ medytsyny - Bulletin of Biological Problems and Medicine, 3, (88), 154-156 [in Ukrainian].

4. Abrosimov, V.V., Avdeev, S.N., \& Avdeeva, O.E. (2007). Chuchalina, A.G. (Ed.). Respiratornaya meditsina: rukovodstvo $v 2 t$. [Respiratory medicine: a guide in 2 vol.]. Moscow: GEOTAR-Media [in Russian].

5. Vatutin, M.T., Honcharenko, T.S., \& Sklianna, O.V. (2005). Flavonoid kvertsetyn: farmakolohichni vlastyvosti ta klinichne vykorystannia [Flavonoide quercetin: pharmacologic authorities and clinical application]. Liky Drugs, 3-4, 19-26 [in Ukrainian].

6. Gavrilov, V.B. \& Mishkorudnaya, M.I. (1989). Spektrofotometricheskoye opredeleniye soderzhaniya gidroperekisey lipidov $v$ plazme krovi. Laboratornaya diagnostika ishemicheskoy bolezni serdtsa [Spectrophotometric determination of the content of lipid hydroperoxides in blood plasma. Laboratory diagnostics of coronary heart disease]. Kyiv: Zdorovia [in Russian].

7. Korobeinikova, E.N. (1989). Modifikatsiya opredeleniya produktov perekisnogo okisleniya lipidov $v$ 
reaktsii s tiobarbiturovoy kislotoy [Modification of the determination of lipid peroxidation products in the reaction with thiobarbituric acid]. Laboratornoye delo-Laboratory Work, 7, 8-10 [in Russian].

8. Fried, R. (1975). Enzymatic and non-enzymatic assay of super oxide dismutase. Biochemie, (57), 65, 657-660.

9. Holmes, R. \& Masters, C. (1970). Epigenetic interconversions of the multiple forms of mouse liver catalase. FEBS Lett., (11), 1, 45-48.
10. Gorizontov, P.D., Belousova, O.I., \& Fedotova, M.I. (1983). Stress i sistema krovi [Stress and blood system]. Moscow: Meditsina [in Russian].

11. Orekhov, O.O., \& Kirilov, Yu.A. (1985). Patomorfologiya legkikh i mikrotsirkulyatornogo rusla malogo kruga krovoobrashcheniya pri khronicheskom eksperimentalnom allergicheskom alveolite [Pathomorphology of the lungs and microcirculatory bed of the small circle of blood circulation in chronic experimental allergic alveolitis]. Arkhiv patologii - Archive of Pathology, 10, 54-61 [in Russian].

\section{ФУНКЦИОНАЛЬНОЕ СОСТОЯНИЕ ПРООКСИДАНТНОЙ И АНТИОКСИДАНТНОЙ СИСТЕМ В ЛЕГКИХ ПРИ ЭКСПЕРИМЕНТАЛЬНОМ АЛЛЕРГИЧЕСКОМ АЛЬВЕОЛИТЕ В УСЛОВИЯХ ИММОБИЛИЗАЦИОННОГО СТРЕССА И КОРРЕКЦИЯ ЕГО НАРУШЕНИЙ КОРВИТИНОМ}

\section{Резюме}

Вступление. Среди заболеваний аллергического генеза бронхолегочного аппарата важное место занимает экспериментальный аллергический альвеолит (ЭАА). Резкое ухудшение социально-экономического положения в Украине, высокое психоэмоциональное напряжение в обществе, длительное систематическое влияние неблагоприятных фракторов часто сочетаются, вызывая в организме стрессовую реакцию.

Цель исследования - изучить фуннкциональное состояние прооксидантной и антиоксидантной систем в легких морских свинок-самок в условиях развития экспериментальных иммобилизационного стресса и аллергического альвеолита и при их коррекции корвитином.

Методы исследования. Объектом исследования были 80 морских свинок-самок, разделенных на 8 экспериментальных групп по 10 животных в каждой: 1-я - интактные животные; 2-4 - экспериментальная модель аллергического альвеолита (1-е, 2-е, 34-е сутки) до лечения корвитином (Борщаговский химико-фрармацевтический завод); 5-7-ЭАА в условиях экспериментального иммобилизационного стресса (ЭИС) (1-е, 2-е, 34-е сутки) до лечения корвитином; 8-я - ЭАА при ЭИС (34-е сутки) после лечения корвитином, который вводили внутрибрюшно в течение 10-ти суток в дозе 40 мг/кг. Затем животных декапитировали и определяли в легких содержание продуктов перекисного окисления липидов и активность ферментов антиоксидантной системы: содержание диеновых конъюгатов - по методу В. Б. Гаврилова, М. И. Мишкорудной, малонового диальдегида - по методу Э. Н. Коробейниковой, активность супероксиддисмутазы - по методу R. Fried, каталазы - по методу R. Holmes, C. Masters. Экспериментальный иммобилизационный стресс воспроизводили по методу П. Д. Горизонтова, экспериментальный аллергический альвеолит - по методу О. О. Орехова, Ю. А. Кирилова. Статистическую обработку цифрровых данных проводили по t-критерию Стьюдента. Статистически достоверными считали результаты, при которых $p \leq 0,05$.

Результаты и обсуждение. Во время экспериментальных исследований наблюдали изменение активности антиоксидантной защиты и перекисного окисления липидов в динамике развития ЭАА, а также изменение равновесия между прооксидантной и антиоксидантной системами в сторону стимуляции прооксидантной и угнетения антиоксидантной. Отмечали значительную активацию антиоксидантных механизмов на 1-е сутки с постепенным истощением на 34-е сутки заболевания и усилением процессов липопероксидации на 34-е сутки. В условиях сочетания патологических процессов (экспериментальных аллергического альвеолита и иммобилизационного стресса) наблюдали значительную стимуляцию прооксидантной и угнетение антиоксидантной систем. После лечения в течение 10-ти дней морских свинок с ЭАА в условиях ЭИС, которым вводили корвитин в дозе 40 мг/ке, значительно угнеталось перекисное окисление липидов и возрастала активность антиоксидантной системы - супероксиддисмутазы.

Выводы. Полученные результаты исследования показали неспособность антиоксидантной системы утилизировать продукты перекисного окисления липидов при ЭАА в условиях ЭИС и ее истощение еще в ранние периоды заболевания. При использовании корвитина, который имеет мембраностабилизирую- 
щее, иммунокорректирующее, противовоспалительное и антиишемическое действие, уменьшилось повреждающее действие перекисного окисления липидов и значительно повысилась антиоксидантная защита, что, в свою очередь, свидетельствует о корректирующем влиянии корвитина на показатели прооксидантной и антиоксидантной систем и дает возможность проводить дальнейшее изучение и экспериментальные исследования.

КЛЮЧЕВЫЕ СЛОВА: экспериментальный аллергический альвеолит; иммобилизационный стресс; корвитин.

M. S. Regeda, M. Ye. Kovalska

DANYLO HALYTSKYI LVIV NATIONAL MEDICAL UNIVERSITY

\section{FUNCTIONAL STATUS OF PROOXIDANT AND ANTIOXIDANT SYSTEMS IN LUNGS WITH EXOGENIC ALERGETIC ALVEOLITIS IN IMMOBILIZATIONAL STRESS AND CORRECTION OF ITS VIOLATIONS BY CORVITIN}

\section{Summary}

Introduction. Experimental allergic alveolitis (EAA) takes an important part among the diseases of the allergic genesis of the bronchopulmonary unit. The sharp deterioration of the socioeconomic situation in Ukraine, the high psycho-emotional stress in society, the long-term systematic impact of adverse factors are often combined, causing a stressful situation in the body.

The aim of the study - to learn the functional state of the prooxidant and antioxidant system in the lungs of the mollusks under the conditions of the development of experimental immobilization stress and experimental allergic alveolitis and their correction with corvitin.

Research Methods. The object - 80 guinea pigs (females) divided into 8 experimental groups, with 10 animals in each. $1^{\text {st }}$ group - intact animals; 2, 3, 4 groups - the experimental model of allergic alveolitis $\left(1^{\text {st }}, 2^{\text {nd }}, 34^{\text {th }}\right.$ day) to the treatment of K.5, 6, 7 groups - EAA under conditions of experimental immobilization stress $(E I S)\left(1^{\text {st }}, 2^{\text {nd }}\right.$, $34^{\text {th }}$ day) to $C$ treatment. Group 8 - EAA in the conditions of EIS (34th day) after treatment C, which for 10 days was administered intravaginal drug "Corvitin" (Borshchahivskyi Chemical and Pharmaceutical factory) in dose of $40 \mathrm{mg} / \mathrm{kg}$. The animals then decapitated and determined in the lungs the content of the LPO products and the activity of the enzymes AOC. The content of diene conjugates (DK) - method of V. H. Havrylov, V. I. Mishkorudna, malone dialdehyde (MDA) - E. N. Korobeinikov, superoxide dismutase activity (SOD) - by R. Fried method, catalase activity (CT) - by B. Holmes, C. Masters. Immobilization stress - by the method of PID Horizon [10]. Experimental $A A$ - by the method of O. Orekhov, Yu. A. Kyrilov. Statistical processing of digital data - Styuden's method. Statistically reliable results were considered, for which $p \leq 0.05$.

Results and Discussion. During experimental studies, there was a change in the activity of antioxidant protection and lipid peroxidation in the dynamics of EAA development. There are changes in the equilibrium between the prooxidant and antioxidant systems in the direction of the growth of prooxidant and inhibition of antioxidant systems. According to the results, there is a significant activation of antioxidant mechanisms before the first day, with a gradual exhaustion up to 34 days of the disease and an increase in the processes of lipoperoxidation up to 34 days. Under conditions of combined pathological processes - experimental $A A$ and immobilization stress, there is a significant stimulation of the antioxidant and prooxidant antioxidant systems. After treatment for ten days, guinea pigs with experimental AA in the conditions of EIS which were administered at a dose of $40 \mathrm{mg} / \mathrm{kg}$ there is a significant inhibition of $\angle P O$, and an increase in the activity of the antioxidant system - superoxide dismutase.

Conclusions. The obtained results of the study showed the failure of the antioxidant system to dispose of the products of the LPA in the experimental AA under stress and its exhaustion in early periods of the disease. With the use of corvetone, which has membrane-stabilizing, immune-regulating, anti-inflammatory and anti-ischemic effects, there was a decrease in the damaging effect of $L P O$ and a significant increase in antioxidant defense, which in turn indicates the corrective effect of corvitin on the parameters of prooxidant and antioxidant systems and provides an opportunity for further study and experimental researches.

KEY WORDS: exogenous allergic alveolitis; immobilization stress; corvitin. 